19. Karthikeyan, P., Mohan, D., Abishek, G. and Priya, R., Synthesis of silver nanoparticles using phytoplankton and its characteristics. Int. J. Fish. Aquat., 2015, 2(6), 398-401.

20. Suja, C. P., Senthil, L. S., Anu Priya, S., Preethi, S. M. and Renu, A., Optimization and characterization of silver nanoparticle synthesis from the microalgae, Isochrysis galbana. Biosci. Biotechnol. Res. Commun., 2016, 9(2), 195-200.

21. Baskar, G., Chandhuru, J., Fahad, K. S., Praveen, A. S., Bharathi, R. and Fyna, S., Mycological synthesis and characterization of silver nanoparticles by Aspergillus species. J. Chem. Pharm. Res., 2015, 7(7), 300-306.

ACKNOWLEDGEMENTS. The present work was carried out with financial support from Kerala State Council for Science, Technology and Environment. We thank the Director, Central Marine Fisheries Research Institute, Cochin and the Director, Sophisticated Test and Instrumentation Centre, Cochin University of Science and Technology, Cochin for providing the necessary facilities for this study. We thank Dr N. K. Sanil (Marine Biotechnology Division, Central Marine Fisheries Research Institute, Cochin) for his help in SEM analysis and Dr N K. Praveen (N.S.S. College, Cherthala) for his help in FT-IR and XRD analysis.

Received 5 July 2019; revised accepted 4 September 2020

\section{Late Quaternary monsoon and productivity variability in the northwestern Arabian Sea}

\author{
Vishwesh K. Pathak*, Ashish Kharwar, Ajai K. Rai \\ and Siddhartha S. Das \\ Department of Earth and Planetary Sciences, University of Allahabad, \\ Prayagraj 211 002, India
}

We studied the changes in planktic foraminiferal distribution along with some sedimentological and geochemical data at ODP Site 722B in the northwestern Arabian Sea to reconstruct monsoon upwelling and productivity variations during the last $\sim 550 \mathrm{kyr}$. The higher relative abundance of Globigerinita glutinata and southwest (SW) monsoon assemblage along with increased $\mathrm{Ba} / \mathrm{Al}$ ratio during most of the interglacial intervals, suggests lateral transport of eutrophic water due to strong upwelling causing enhanced productivity. A relatively higher test fragmentation and increased relative abundance of Globorotalia menardii during interglacial intervals indicate increased carbonate dissolution. The glacial-interglacial transitions are

\footnotetext{
*For correspondence. (e-mail: vishweshk10@gmail.com)
}

characterized by abrupt increase in the SW monsoon upwelling assemblage and $\mathrm{Ba} / \mathrm{Al}$ ratio, suggesting more intensified upwelling and productivity due to accelerated SW monsoon and weak northeast monsoon conditions. Spectral analysis of the abundance data of SW monsoon upwelling assemblage and $\mathrm{Ba} / \mathrm{Al}$ ratio demonstrates the 100 -kyr cycle showing glacialinterglacial frequency and $23-\mathrm{kyr}$ cycle indicating precession-driven insolation variability.

Keywords: Foraminifera, interglacial intervals, monsoon upwelling, productivity variability.

THE seasonal changes in the current direction, upwelling and mixed layer characters such as temperature, nutrient content and productivity in the Arabian Sea are the oceanic response of strong monsoonal winds ${ }^{1,2}$. The presentday ocean circulation pattern of the Arabian Sea is driven by monsoons. The monsoon is a result of inter-tropical convergence zone as well as the differential heating of the Asian continent and the Indian Ocean. Monsoon causes a semi-annual reversal of the current patterns in response to changes in wind direction. The southwest (SW) monsoon develops between June and September, whereas the northeast (NE) monsoon develops between November and $\mathrm{March}^{3}$. The differential (land-sea) sensible heating and heating of troposphere through latent heat induce the SW monsoon, which develops a characteristic circulation pattern in the atmosphere with changes in the wind direction ${ }^{4}$. The surface water of northwestern Arabian Sea is dragged by monsoonal winds. The coastal upwelling off Somalia, Oman and southwestern India is the result of clockwise circulation of surface waters during the SW monsoon, whereas a NE-trending narrow, low-level atmospheric Findlater Jet blowing across the Arabian Sea is responsible for open-ocean upwelling ${ }^{5-9}$. Naidu and Malmgren ${ }^{10}$ suggested that the seasonal differences in sea surface temperature (SST) have a direct relation with the upwelling strength in the northwestern Arabian Sea. The upwelling leads to a major increase in productivity ${ }^{11}$, which results into the development of characteristic assemblage of planktic foraminiferal species.

Earlier studies revealed that the changing northern hemisphere summer insolation is the major factor that influences the timing and strength of monsoonal winds ${ }^{4,12,13}$. The strong SW monsoon induced by insolation maxima is probably responsible for the enhanced productivity. Intensified wind and increased upwelling off the Somalia and Oman coasts, especially during interglacials, occurred due to intense SW monsoon ${ }^{14}$. A relatively weaker anticlockwise flow of surface current during the interval of the NE monsoon ${ }^{15}$ results in surface water cooling and convective overturning ${ }^{16}$. The convective overturning injects nutrient-rich water into the surface waters ${ }^{17}$, which is considered to dominantly control winter productivity that remains relatively low than the 


\section{RESEARCH COMMUNICATIONS}

summer productivity ${ }^{18}$. Several researchers have studied the late Quaternary planktic foraminiferal assemblages in the northwestern Arabian Sea to reconstruct monsooninduced upwelling and productivity changes ${ }^{6,7,10,19-20}$. Most of the earlier late Quaternary planktic foraminiferal studies were based on the cores recovered along the Oman margin in the coastal upwelling area. Therefore, we selected a late Quaternary section in relatively offshore, open-ocean upwelling region for the study, to better understand the influence of monsoon on productivity changes in the entire northwestern Arabian Sea.

Planktic foraminifera are useful monsoon indicators because they directly respond to changes in the ocean environment due to monsoonal changes $8,10,19-26$. As the characteristic oceanographic conditions are produced due to SW and NE monsoons, the planktic foraminiferal composition can be used for the reconstruction of monsoonal changes ${ }^{27}$. The main objective of this study is to understand the pattern of upwelling and primary productivity in response to the monsoon variability over the past $550 \mathrm{kyr}$ in the northwestern Arabian Sea, on the basis of planktic foraminiferal record. ODP site $722 \mathrm{~B}$ is located on Owen Ridge in the northwestern Arabian Sea (lat. $16^{\circ} 37.31^{\prime} \mathrm{N}$; long. $\left.59^{\circ} 47.76^{\prime} \mathrm{S}\right)$, well below the presentday oxygen minimum zone (OMZ) at $2028 \mathrm{~m}$ water depth (Figure 1).

The present study is based on a total of 84 samples collected from about $21 \mathrm{~m}$ thick section at $25 \mathrm{~cm}$ intervals. The studied section mainly comprises alternate light and dark layers of foraminifera-rich calcareous nannofossil ooze. Each sample was treated with $10 \%$ calgon solution and water in the $1: 3$ ratio for about $24 \mathrm{~h}$, washed over a $125 \mu \mathrm{m}$ Tyler sieve and dried in a hot-air oven at $50^{\circ} \mathrm{C}$. A microsplitter was used to split the processed samples of $>125 \mu \mathrm{m}$ fraction to a suitable aliquot to obtain approximately 300 individuals of planktic foraminifera. All the planktic foraminiferal specimens from the splitted samples were picked, mounted on microfaunal slides, identified and counted. The percent abundances of dominant species were plotted against time (ka). Following Caley et $a l .{ }^{28}$, the characteristic planktic foraminiferal species were grouped as SW monsoon upwelling assemblage comprising Globigerina bulloides, Neogloboquadrina pachyderma (sinistral), Globigerinita glutinata, Neogloboquadrina dutertrei, Globorotalia scitula, Pulleniatina obliquiloculata, Globigerinita parkerae, Globorotaloides hexagona, Globorotalia menardii and Globorotalia theyeri, and NE monsoon assemblage consisting of Globigerina falconensis, Globigerinella aequilateralis, Globigerinoides ruber, Orbulina universa, Globigerinoides sacculifer, Globigerinoides triloba, Globigerinoides tenella, Globigerinella calida and Globigerinita uvula. To understand the dissolution effect on planktic foraminifera, we calculated the fragmentation (number of fragments/(number of fragments + complete tests) $\times 100$ ), after Ivanova ${ }^{29}$. The $\mathrm{Ba} / \mathrm{Al}$ and $\mathrm{P} / \mathrm{Al}$ ratio data were taken from Shimmield and Mowbray ${ }^{30}$. For determining biogenic carbonate content of bulk sediment, the samples were dried in a hot-air oven and treated with glacial acetic acid. Organic carbon content of each sample was also measured using titration method proposed by Gaudette et al. ${ }^{31}$. Spectral analysis was performed on SW monsoon upwelling assemblage data and $\mathrm{Ba} / \mathrm{Al}$ geochemical proxy data. Both the datasets were standardized for analysis. Redfit spectral analysis method was used in the Past 3.25 software $^{32}$. In the Redfit method, rectangle window is used with Oversample 5 and segment 1 . The timedepth relationship for calculation of age of each sample and planktic foraminiferal oxygen isotopic data provided by Clemens and Prell ${ }^{33}$ was used in the present study.

The abundant planktic foraminiferal species consistently present during the late Quaternary at ODP site 722B were mainly G. glutinata, G. bulloides, N. pachyderma (dextral coiling), G. menardii and G. ruber. Being the most

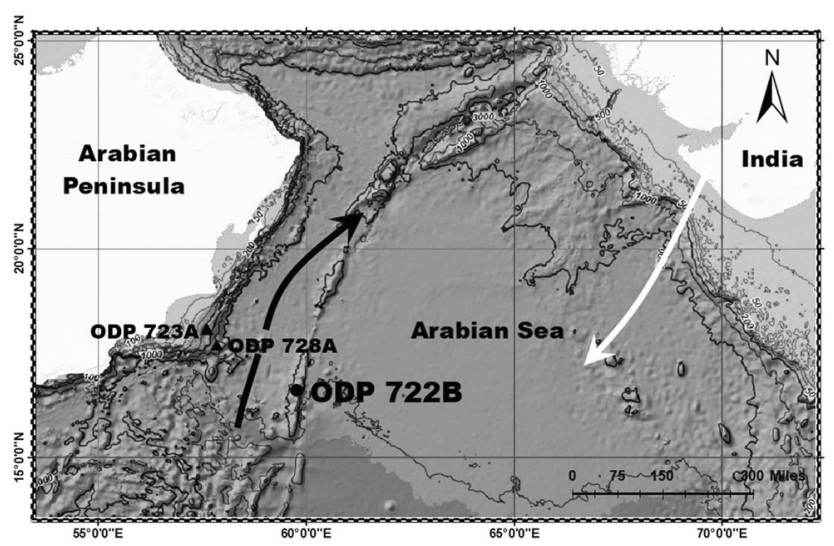

Figure 1. Location map of ODP site $722 \mathrm{~B}$ (present study) and two other sites, viz. ODP $723 \mathrm{~A}^{7}$ and ODP $728 \mathrm{~A}^{20}$ in the northwestern Arabian Sea. Black arrow indicates southwest (SW) monsoon and white arrow indicates northeast (NE) monsoon.

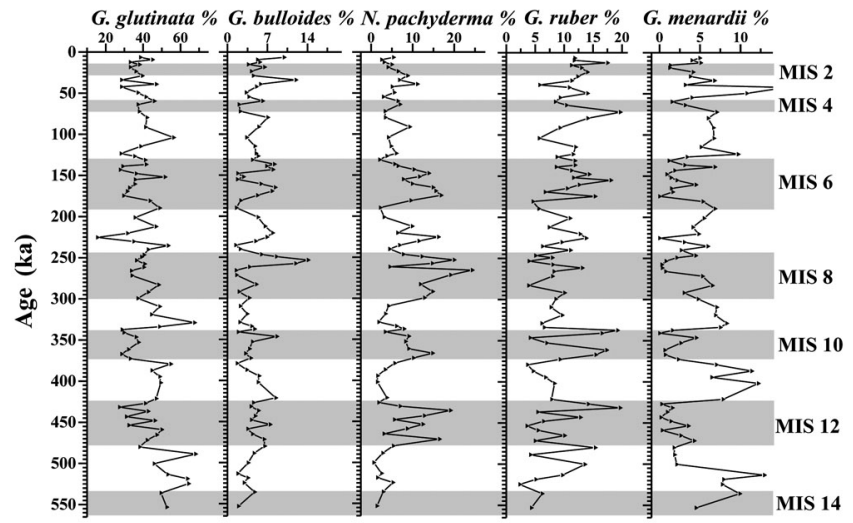

Figure 2. Time-series plots of relative abundance of Globigerinita glutinata, Globigerina bulloides, Neogloboquadrina pachyderma, Globigerinoides ruber and Globorotalia menardii. Glacial stages are indicated by light grey shading. 


\section{RESEARCH COMMUNICATIONS}

dominant species, G. glutinata constituted approximately $50 \%$ of the total planktic foraminiferal assemblage. In general, its relative abundance ranges between $40 \%$ and $60 \%$. During most of the interglacial intervals, G. glutinata showed relatively higher abundance (Figure 2). This species was also characterized by distinct increase in its relative abundance across glacial/interglacial transitions. The relative abundance of $N$. pachyderma was marked with approximately reverse pattern compared to G. glutinata and remained relatively high during glacial stages (Figure 2). G. bulloides occured consistently (average $\sim 5 \%)$ throughout the examined section, but its relative abundance did not show any clear trend with respect to glacial/interglacial stages. G. ruber was abundant during most of the glacial intervals (Figure 2). During interglacial stages $G$. menardii showed higher relative abundance (Figure 2). The SW monsoon upwelling assemblage dominated during most of the interglacial intervals, whereas the NE monsoon assemblage showed dominant occurrence during glacial intervals (Figure 3). G. glutinata was marked with prominently higher relative abundance during interglacial MIS 13, which also coincided with a marked increase in fragmentation (Figure 2).

The fragmentation of foraminiferal tests remained high during most of the interglacial intervals (Figure 4). This closely corresponds with relatively increased abundance of a dissolution resistant species, G. menardii. Percentage of total carbonate remained significantly high during the interglacial intervals (Figure 4). The percentage of organic carbon content did not show any definite pattern with respect to glacial and interglacial intervals. The $\mathrm{Ba} / \mathrm{Al}$ and $\mathrm{P} / \mathrm{Al}$ ratios also had a similar pattern and remained high during interglacial intervals (Figure 3).

Spectral analysis was applied to the percentage data of SW monsoon upwelling assemblage and $\mathrm{Ba} / \mathrm{Al}$ ratio. Both these proxies clearly show the 100 and $23 \mathrm{kyr}$ cycles, i.e. the orbital cycles of eccentricity and precession, but the 41-kyr cycle was not well-marked (Figure 5).

The dominant species of planktic foraminifera found at ODP site 722B were also present in several areas of upwelling in the Arabian Sea ${ }^{25,27}$. G. bulloides prefers to live in subpolar areas, tropical regions of upwelling and monsoonal upwelling areas like Oman margin, and is widely used as a productivity indicator ${ }^{19,23,34}$. G. bulloides and G. glutinata are characteristic SW monsoon upwelling species abundantly distributed in the upwelling regions off Somalia ${ }^{26}$. G. glutinata is abundantly distributed in the areas of open-ocean upwelling. However, $G$. bulloides occurs dominantly in the regions of coastal upwelling ${ }^{7}$. The higher relative abundance of $G$. glutinata along with increased percentage of SW monsoon upwelling assemblage during most of the interglacial periods at ODP site 722B reflects increased open-ocean upwelling. The higher $\mathrm{Ba} / \mathrm{Al}$ and $\mathrm{P} / \mathrm{Al}$ ratios along with increased percentage of biogenic carbonate suggest enhanced productivity in this region. Thus, the intensified SW mon- soonal upwelling during interglacial periods is probably responsible for higher productivity. This is in agreement with the suggestion that interglacials are the intervals of intensified SW monsoon ${ }^{4,6,25,35}$. The interglacial interval was almost analogous to the present-day environment showing strong seasonality, changing interannual productivity phases and significant variation in surface-water stratification. On the basis of increased frequencies of $G$. glutinata and $G$. bulloides along with higher peaks of total planktic foraminiferal tests during interglacial periods in the northwestern Arabian Sea, Ishikawa and $\mathrm{Oda}^{36}$ also suggested higher productivity due to intense SW monsoon upwelling. We recorded distinctly increased percentage of G. glutinata and fragmentation during MIS 13, reflecting a significantly high productivity. Ziegler et al. ${ }^{37}$ suggested that the prominent increase in primary productivity and extreme carbonate dissolution in the Arabian Sea during MIS 13 was possibly the result of the development of an extensive meridional overturning

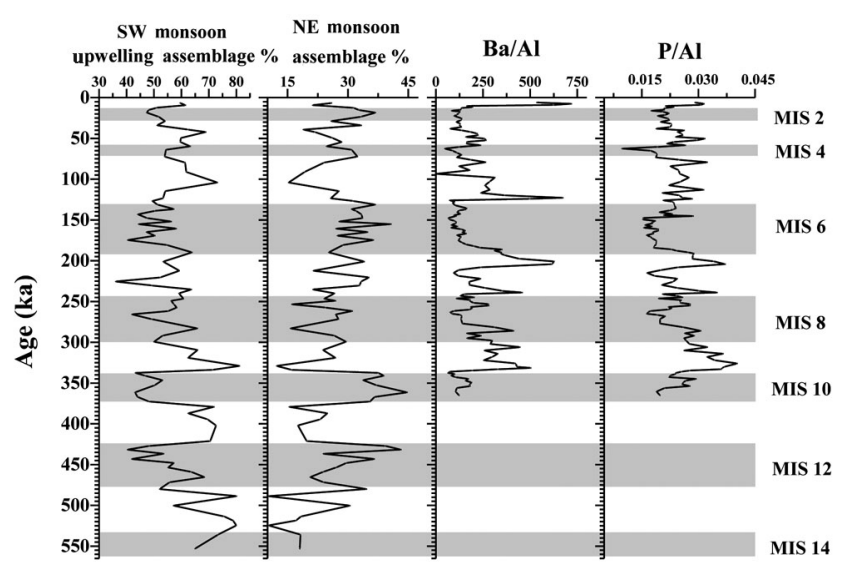

Figure 3. Time-series plots of SW monsoon upwelling assemblage $(\%)$, NE monsoon assemblage $(\%)$, and $\mathrm{Ba} / \mathrm{Al}$ and $\mathrm{P} / \mathrm{Al}$ ratios ${ }^{30}$. Glacial stages are indicated by light grey shading.

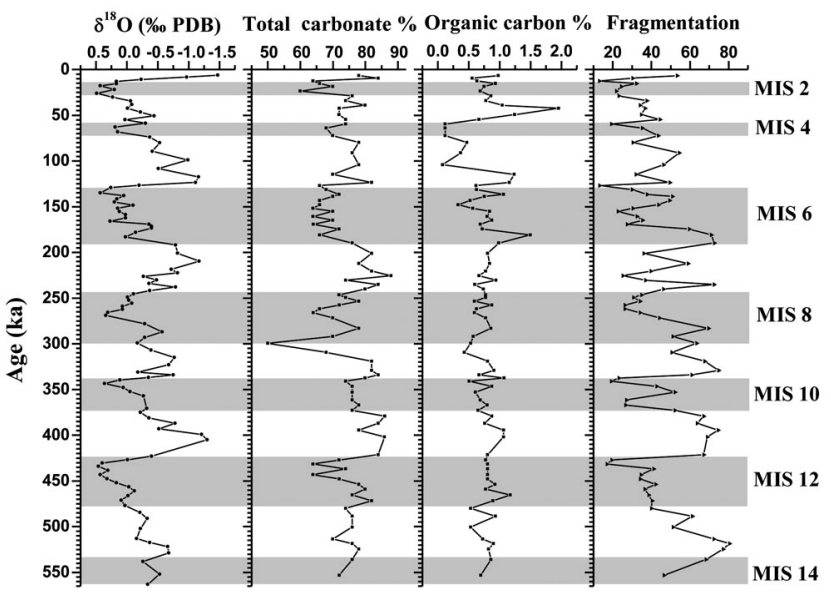

Figure 4. Time-series plots of planktic foraminiferal $\delta^{18} \mathrm{O}$ values ${ }^{33}$, total carbonate $(\%)$, organic carbon $(\%)$ and test fragmentation. Glacial stages are indicated by light grey shading. 

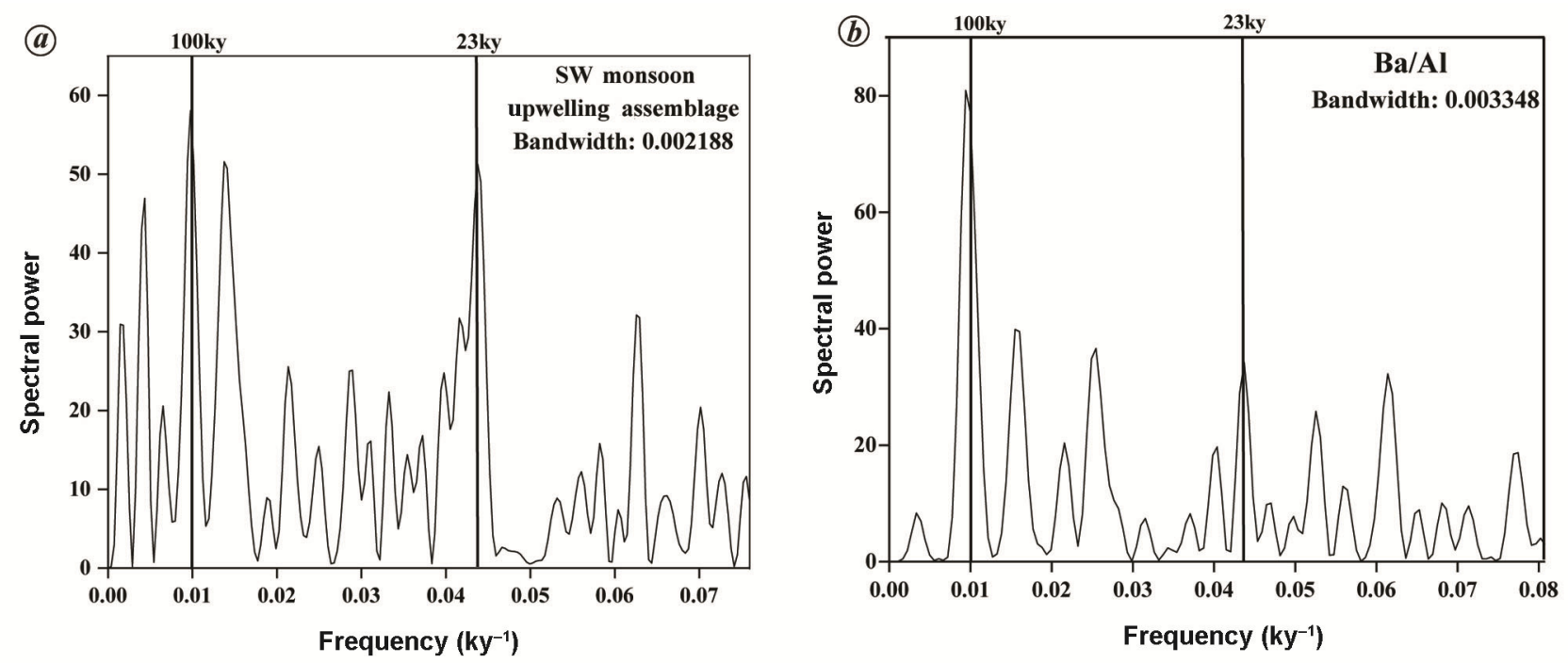

Figure 5. Spectral analysis results of (a) SW monsoon upwelling assemblage and (b) Ba/Al data. Spectral peaks marked with their periodicities are with $>90 \%$ significance.

circulation in the Atlantic Ocean towards the end of MidPleistocene transition. This was probably responsible for the upwelling of nutrient-rich deep waters into the Indian Ocean euphotic zone and resulting into a distinct increase in productivity.

The increased relative abundance of the NE monsoon assemblage during most of the glacial intervals suggests intensified NE monsoon, which also coincides with the increased percentage of $N$. pachyderma and G. ruber. $N$. pachyderma commonly thrives in polar and sub-polar areas, and is generally used to understand the palaeoenvironment of cold oceans ${ }^{4,38,39}$. Hilbrecht ${ }^{40}$ and Schiebel et $a l .^{41}$ suggested that the strong stratification and deep chlorophyll maxima control the distribution of $N$. pachyderma. The nutrients due to convective overturning also increase the productivity during NE monsoon ${ }^{42}$. AlmogiLabin et $a l .{ }^{43}$ reported the occurrence of characteristic benthic foraminiferal assemblages suggesting increased productivity during glacial intervals in the Gulf of Aden, a region under the influence of the NE monsoon.

During glacial/interglacial transitions, the NE monsoon assemblage is replaced by a significant increase in the abundance of SW monsoon upwelling assemblage, indicating substantial increase in upwelling and productivity. The planktic foraminiferal $\delta^{18} \mathrm{O}$ significantly decreases across the transitions, reflecting abruptly increased sea surface temperature and change in the global ice volume. The rapid melting of inland glaciers due to increase in temperature is responsible for intensified SW monsoon and relatively weaker NE monsoon ${ }^{44}$. Thus, the sudden shift in planktic foraminiferal assemblage and higher $\mathrm{Ba} / \mathrm{Al}$ ratio across the glacial/interglacial transitions suggest prominent increase in upwelling and productivity due to intensified SW monsoon along with decline in the NE monsoon.
In frequency analysis, both SW monsoon upwelling assemblage and $\mathrm{Ba} / \mathrm{Al}$ ratio were characterized by dominant occurrence of 100-kyr (eccentricity) orbital cycles reflecting glacial-interglacial cyclicity in monsoonal upwelling history and productivity in the northwestern Arabian Sea. Thus, the prominent occurrence of 100-kyr cycles suggests that the global ice volume changes indirectly control the degree of productivity. Both the SW monsoon upwelling assemblage and $\mathrm{Ba} / \mathrm{Al}$ ratio also demonstrate coherence with 23-kyr (precession) band. The precession cycle is also widely reported in various productivity proxies of the Arabian Sea ${ }^{4,7,12,36,43}$. The presence of these two cycles suggests that productivity in the open-ocean upwelling region of the northwestern Arabian Sea is influenced by glacial-interglacial variations and changes in the insolation. The planktic foraminiferal assemblages in the coastal upwelling sites ODP 723A (ref. 7) and 728A (ref. 20) on the Oman margin in the northwestern Arabian Sea, also indicate similar glacialinterglacial variations. Recently, Saraswat et al. $^{45}$ reported that planktic foraminiferal assemblages at site IODP355 U1457 in the northeastern Arabian Sea reflecting glacial-interglacial changes show close resemblance with the multi-proxy summer monsoon stack $^{46}$ and also with past productivity estimated from bromine in the northern Arabian Sea ${ }^{37}$. Thus, a close correspondence in the changes of various proxies between northwestern and northeastern Arabian Sea regions suggests that the whole northern Arabian Sea had been influenced simultaneously by the glacial-interglacial variations.

The higher test fragmentation along with dominant occurrence of $G$. menardii suggests strong carbonate dissolution during most of the interglacial periods. The increased upwelling during interglacial periods supplies large amounts of organic matter to the intermediate 


\section{RESEARCH COMMUNICATIONS}

waters and carbon dioxide is produced due to its remineralization, which make the intermediate waters more corrosive with respect to carbonate ${ }^{7}$. Witte and Pfannkuche $^{47}$ recorded increased benthic carbon mineralization and higher rates of oxygen utilization at bathyal to abyssal depths of the northwestern Arabian Sea, which are influenced by higher rates of organic matter fluxes during the SW monsoon. Schmiedl and Leuschner ${ }^{48}$ also suggested that the increased amount and rate of organic matter fluxes, and thus pore water acidification resulting into higher carbonate dissolution are restricted to the interglacial conditions during periods of strong SW monsoon.

1. Wyrtki, K., Oceanographic Atlas of the International Indian Ocean Expedition, National Science Foundation, Washington DC, USA, 1971, p. 531.

2. Wyrtki, K., Physical oceanography of the Indian Ocean. In The Biology of the Indian Ocean (ed. Zeitschel, B.), Springer, Berlin, Germany, 1973, pp. 18-36.

3. Webster, P. J., The Elementary Monsoon, Monsoons. Wiley, New York, USA, 1987, pp. 3-32.

4. Clemens, S. C., Prell, W. L., Murray, D., Shimmied, G. and Weedon, G., Forcing mechanisms of the Indian Ocean monsoon. Nature, 1991, 353, 720-725.

5. Findlater, J., The low-level cross equatorial air current of the western Indian Ocean during the northern summer. Weather, 1974, 29, 411-416.

6. Anderson, D. M. and Prell, W. L., Coastal upwelling gradient during the late Pleistocene. In Proceedings of the Ocean Drilling Program. Scientific Results (eds Prell, W. L. et al.), 1991, vol. 117 , pp. $265-276$

7. Anderson, D. M. and Prell, W. L., A $300 \mathrm{kyr}$ record of upwelling off Oman during the late Quaternary: evidence of the Asian SW monsoon. Paleoceanography, 1993, 8, 193-208.

8. Brock, J. C., McLain, C. R., Anderson, D. M., Prell, W. L. and Hay, W. W., Southwest monsoon circulation and environments of Recent planktonic foraminifera in the northwestern Arabian Sea. Paleoceanography, 1992, 7, 799-813.

9. Lee, C. M., Jones, B. H., Brink, K. H. and Fischer, A. S., The upper ocean response to monsoonal forcing in the Arabian Sea: seasonal and spatial variability. Deep-Sea Res. II, 2000, 47, 11771226 .

10. Naidu, P. D. and Malmgren, B. A., Seasonal sea surface temperature contrast between the Holocene and last glacial period in the western Arabian Sea (Ocean Drilling Project Site 723A): modulated by monsoon upwelling. Paleoceanography, 2005, 20, PA1004; doi:10.1029/2004PA001078.

11. Bauer, S., Hitchcock, G. and Olson, D., Influence of monsoonallyforced Ekman dynamics upon the surface layer depth and plankton biomass distribution in the Arabian Sea. Deep Sea Res., Part A, 1991, 38, 531-553.

12. Reichart, G. J., Lourens, L. J. and Zachariasse, W. J., Temporal variability in the north Arabian Sea oxygen minimum zone (OMZ) during the 225,000 years. Paleoceanography, 1998, 13, 607621

13. Schulz, H., von Rad, U. and Erlenkeuser, H., Correlation between Arabian Sea and Greenland climate oscillations of the past 110,000 years. Nature, 1998, 393, 54-57.

14. Sirocko, F., Sarnthein, M., Lange, H. and Erlenkeuser, H., Atmospheric summer circulation and coastal upwelling in the Arabian Sea during the Holocene and the last glaciations. Quaternary Res., 1991, 36, 72-93.

15. Qasim, S. Z., Oceanography of the northern Arabian Sea. DeepSea Res., 1982, 29/9A, 1041-1068.
16. Bartolacci, D. M. and Luther, M. E., Patterns of co-variability between physical and biological parameters in the Arabian Sea. Deep-Sea Res. II, 1999, 46, 1933-1964.

17. Banse, K., On the coupling of hydrography, phytoplankton, zooplankton, and settling organic particles offshore in the Arabian Sea. Proc. Indian Acad. Sci., Sect. A, 1994, 103/2, 125-161.

18. Madhupratap, M., Kumar, S. P., Bhattathiri, P. M. A, Kumar, M. D., Raghukumar, S., Nair, K. K. C. and Ramaiah, N., Mechanism of the biological response to winter cooling in the northeastern Arabian Sea. Nature, 1996, 384, 549-552.

19. Gupta, A. K., Anderson, D. M. and Overpeck, J. T., Abrupt changes in the Asian southwest monsoon during the Holocene and their links to the North Atlantic Ocean. Nature, 2003, 421, 354357; Pub Med, doi:10.1038/nature01340.

20. Rai, A. K. and Das, S. S., Late Quaternary changes in surface productivity and oxygen minimum zone (OMZ) in the northwestern Arabian Sea: micropaleontologic and sedimentary record at ODP site 728A. J. Earth Syst. Sci., 2011, 120, 113-121.

21. Cullen, J. L. and Prell, W. L., Planktonic foraminifera of the northern Indian Ocean: distribution and preservation in surface sediments. Mar. Micropaleontol., 1984, 9, 1-52.

22. Naidu, P. D. and Malmgren, B. A., A 2200 years periodicity in the Asian monsoon system. Geophys. Res. Lett., 1995, 22, 2361-2364.

23. Naidu, P. D. and Malmgren, B. A., A high-resolution record of late Quaternary upwelling along the Oman Margin, Arabian Sea based on planktonic foraminifera. Paleoceanography, 1996, 11, 129-140.

24. Gupta, A. K., Das. M. and Anderson, D. M., Solar influence on the Indian summer monsoon during the Holocene. Geophys. Res. Lett., 2005, 32, L17703; doi:10.1029/2005GL022685.

25. Ivanova, E., Schiebel, R., Singh, A. D., Schmiedl, G., Niebler, H. S. and Hemleben, C., Primary production in the Arabian Sea during the last 135,000 years. Palaeogeogr. Palaeoclimatol. Palaeoecol., 2003, 197, 61-82.

26. Schiebel, R., Zeltner, A., Treppke, U. F., Waniek, J. J., Bollmann, J., Rixen, T. and Hemleben, C., Distribution of diatoms, coccolithophores and planktic foraminifers along a trophic gradient during southwest monsoon in the Arabian Sea. Mar. Micropaleontol., 2004, 51, 345-371.

27. Conan, S. M. H. and Brummer, G. J. A., Fluxes of planktonic foraminifera in response to monsoonal upwelling of the Somalia Basin margin. Deep-Sea Res. III, 2000, 47, 2207-2227.

28. Caley, T. et al., New Arabian Sea records help decipher orbital timing of Indo-Asian monsoon. Earth Planet. Sci. Lett., 2011, 308 433-444; http://dx.doi.org/10.1016/j.eps1.2011.06.019.

29. Ivanova, E. V., Late Quaternary paleoceanology (based on planktonic foraminifers and pteropods). P. P. Shirshov Institute of Oceanology USSR, Academy of Science, Moscow, 1988, p. 139 (in Russian).

30. Shimmield, G. B. and Mowbray, S. R., The inorganic geochemical record of the northwest Arabian Sea: a history of productivity variation over the last $400 \mathrm{ky}$ from sites 722 and 724. In Proceedings of the Ocean Drilling Program. Scientific Results (eds Prell, W. L. et al.), 1991, vol. 117, pp. 409-429.

31. Gaudette, H. E., Flight, W. R., Toner, L. and Folger, D. W., An inexpensive titration method for the determination of organic carbon in recent sediments. J. Sediment. Petrol., 1974, 44, 249-253.

32. Hammer, Ø., Harper, D. A. T. and Ryan, P. D., PAST: paleontological statistics software package for education and data analysis. Palaeontol. Electron., 2001, 4, 9; http://palaeo-electronica.org/ 2001_1/past/issue1_01.htm.

33. Clemens, S. C. and Prell, W. L., One million year record of summer monsoon and continental aridity from Owen Ridge (Site 722) Northwest Arabian Sea. In Proceedings of the Ocean Drilling Program. Scientific Results (eds Prell, W. L. et al.), 1991, vol. 117, pp. 365-388.

34. Curry, W. B., Ostermann, D. R., Guptha, M. V. S. and Ittekot, V., Foraminiferal production and monsoonal upwelling in the Arabian 
Sea: evidence from sediment traps. In Upwelling Systems: Evolution Since the Early Miocene (eds Summerhays, C. P., Prell, W. L. and Emeis, K. C.), Geological Society Special Publication, 1992, vol. 64, pp. 93-106.

35. Emeis, K. C., Anderson, D. M., Doose, H., Kroon, D. and SchulzBull, D., Sea surface temperatures and history of monsoon upwelling in the northwest Arabian Sea during the last 500,000 years. Quaternary Res., 1995, 43, 355-361.

36. Ishikawa, S. and Oda, M., Reconstruction of Indian monsoon variability over the past 230,000 years: planktic foraminiferal evidence from the NW Arabian Sea open ocean upwelling area. Mar. Micropaleontol., 2007, 63, 143-154.

37. Ziegler, M. L., Lourens, L. J., Tuenter, E. and Reichart, G. J., High Arabian Sea productivity conditions during MIS 13 -odd monsoon event or intensified overturning circulation at the end of the Mid-Pleistocene transition? Climate Past, 2010, 6, 63-76.

38. Be', A. W. H. and Hutson, W. H., Ecology of planktonic foraminifera and biogeographic patterns of life and fossil assemblages in the Indian Ocean. Micropaleontology, 1977, 23, 369-414.

39. Hemleben, C., Spindler, M. and Anderson, O. R., Modern Planktic Foraminifera, Springer-Verlag, New York, USA, 1989, p. 363.

40. Hilbrecht, H., Morphologic gradation and ecology in Neogloboquadrina pachyderma and $N$. dutertrei (planktic foraminifera) from core top sediments. Mar. Micropaleontol., 1997, 31, 31-43.

41. Schiebel, R., Waniek, J., Bork, M. and Hemleben, C., Planktic foraminiferal production stimulated by chlorophyll redistribution and entrainment of nutrients. Deep-Sea Res. I, 2001, 48, 721-740.

42. Veldhuis, M. J. W., Kraay, G. W., van Bleijswijk, J. D. L. and Baars, M. A., Seasonal and spatial variability in phytoplankton biomass, productivity and growth in the Indian Ocean: the southwest and northeast monsoon, 1992-1993. Deep-Sea Res. I, 1997, 44, 425-449.

43. Almogi-Labin, A., Schmiedl, G., Hemleben, C., Siman-Tov, R., Segl, M. and Meischner, D., The influence of the NE winter monsoon on productivity changes in the Gulf of Aden, NW Arabian Sea, during the last $530 \mathrm{ka}$ as recorded by foraminifera. Mar. Micropaleontol., 2000, 40, 295-319.

44. Rogalla, U. and Andruleit, H., Precessional forcing of coccolithophore assemblages in the northern Arabian sea: implications for monsoonal dynamics during the last 200,000 years. Mar. Geol., 2005, 217, 31-48

45. Saraswat, R. et al., Inconsistent change in surface hydrography of the eastern Arabian Sea during the last four glacial-interglacial intervals. Geol. Mag., 2019; https://doi.org/10.1017/S0016756819001122.

46. Clemens, S. C. and Prell, W. L., A 350,000 year summer-monsoon multi-proxy stack from the Owen Ridge, northern Arabian Sea. Mar. Geol., 2003, 201, 35-51.

47. Witte, U. and Pfannkuche, O., High rates of benthic carbon remineralisation in the abyssal Arabian Sea. Deep Sea Res. II, 2000, 47, 2785-2804.

48. Schmiedl, G. and Leuschner, D. C., Oxygenation changes in the deep western Arabian Sea during the last 190,000 years: productivity versus deep-water circulation. Paleoceanography, 2005, 20, PA2008; doi:10.1029/2004PA001044.

ACKNOWLEDGEMENTS. We thank the Ocean Drilling Program (ODP) for providing core samples for the present work, and the anonymous reviewer for valuable suggestions that helped improve the manuscript. The present work was partially supported by the grant provided to V.K.P. under INSPIRE Fellowship by Department of Science and Technology, New Delhi.

Received 10 January 2020; revised accepted 15 October 2020

doi: $10.18520 / \mathrm{cs} / \mathrm{v} 119 / \mathrm{i} 11 / 1833-1838$

\section{Perindopril improves cardiac function in doxorubicin-induced cardiotoxicity rats}

\author{
Li-juan Shen ${ }^{1}$, Yong-hua Zhou ${ }^{2}$, Jin-gui Wang ${ }^{3}$, \\ Lan $\mathrm{Li}^{4}$ and Shu $\mathrm{Lu}^{5, *}$
}

${ }^{1}$ Department of ICU, Wuxi Hospital of Traditional Chinese Medicine, Wuxi Affiliated Hospital Nanjing University of Traditional Chinese Medicine, Wuxi 214071, Jiangsu, China

${ }^{2}$ Jiangsu Institute of Parasitic Diseases, Key Laboratory on Technology for Parasitic Disease Prevention and Control, Ministry of Health, Jiangsu Provincial Key Laboratory on Molecular Biology of Parasites, Jiangsu Provincial Key Subject on Parasitic Diseases,

Wuxi 214064, China

${ }^{3}$ Department of Medical Affairs,

${ }^{4}$ Department of Ultrasonography, and

${ }^{5}$ Department of Cardiology, Wuxi Hospital of Traditional Chinese Medicine, Wuxi Affiliated Hospital Nanjing University of Traditional Chinese Medicine, Wuxi 214071, Jiangsu, China

The present study aimed to observe the effect of perindopril on cardiac function in doxorubicininduced cardiotoxicity rats and explore the underlying molecular mechanisms. We constructed a doxorubicin-induced cardiotoxicity rat model $\left(1.0 \mathrm{mg} \mathrm{kg}^{-1}\right.$, biweekly) for six weeks. Rats in the doxorubicininduced cardiotoxicity group exhibited impaired cardiac function, disorganized sarcomeres and increased levels of brain serum natriuretic peptide, creatine kinase isozyme MB and troponin I. In addition, compared to normal hearts, doxorubicin-induced cardiotoxicity hearts exhibited significantly higher levels of angiotensinogen, angiotensin II (Ang II), angiotensin II type 1 receptor, protein kinase $C$, reactive oxygen species (ROS), high mobility group box 1 (HMGB1), nuclear factor kappa $B$, tumour necrosis factor- $\alpha$, interleukin-6 as well as interleukin- $\beta$. Positive correlation was found among Ang II, ROS and HMGB1. After treatment with an angiotensin-converting enzyme inhibitor perindopril, cardiac function and inflammation induced by doxorubicin had distinctly improved. Intriguingly, the levels of Ang II, ROS and HMGB1 decreased significantly. Our findings suggest that perindopril improves cardiac function in doxorubicin-induced cardiotoxicity rats, which might be related with Ang II/ROS/HMGB1.

Keywords: Cardiac function, doxorubicin-induced cardiotoxicity, myocardial injury, perindopril, rat model, reactive oxygen species.

DOXORUBICIN as a broad-spectrum antitumour anthracycline derived from Streptomyces, is widely used to treat a variety of cancers ${ }^{1}$. The serious adverse effects of doxorubicin on cardiac toxicity limit its clinical applications $^{2}$. Doxorubicin can promote congestive heart failure when it exceeds the cumulative dose of $400-700 \mathrm{mg} / \mathrm{m}^{2}$

*For correspondence. (e-mail: panda55007@163.com) 